\title{
HOMESTAY BUSINESS STANDARS TRAINING FOR HOMESTAY OWNER ON HARAPAN ISLAND
}

\author{
Levyda, Giyatmi, Ekayana Sangkasari Paranita \\ Universitas Sahid, Indonesia. \\ levyda_mm@yahoo.co.id
}

\begin{abstract}
Harapan Island is one of the islands in Kecamatan Kepulauan Seribu Utara which is visited by many tourists. This condition encourages local residents to commercialize their residences as homestays. Homestay required to meet the standards. However, there are still many homestay owners who do not understand about business standards and do not have a certificate, therefore training is needed on homestay standards for owners. The purpose of the training is to increase knowledge about the standards of the homestay business and improve the attitude of the owner. The training was attended by $23 \%$ of homestay owners. Training materials include homestay products, services and management. Material refers to regulations regarding the standard of homestay business. The training method used is reading, material presentation, self-evaluation and discussion. The standard that has not been fulfilled is the provision of a kitchen for guests, guest identity recording, availability of price lists and development of human resources. The results of the training evaluation indicate an increase in knowledge and acceptance of homestay owners. Training evaluation showed that there was an increase in knowledge and changes in the attitude of the trainees. Training is still needed to improve the knowledge and improvement of the attitude of homestay owners.
\end{abstract}

Keywords: Homestay Business Standard, Knowledge And Acceptance Of Training Participants, Training Evaluation

\section{INTRODUCTION}

Administratively, Pulau Harapan Village is in Kecamatan Kepulauan Seribu Utara. Sub district of Harapan Island consists of three administrative units. The area of the island of Harapan is $2.4472 \mathrm{~km}^{2}$ and is inhabited by 2070 people. The livelihoods of 287 people are fishermen, 111 people as traders, 337 workers, and 47 civil servants (North Thousand Islands in Figure, 2018).

North Thousand Islands Village is designated as National Marine Park. Based on its utilization the park is divided into the core zone of the marine park area which is absolutely protected, the zone for protection which is the refutation of the initiation zone, the zone for tourism and the residential zone The core zone is the area absolutely protected and that should not be changed in humans. The tourism zone includes the waters of Nyamplung Island, Kayu Angin Island, Genteng Island, Tiger Island, Perak Island, Bulat Island, Bira Island and Princess Island and others have marine tourism attraction. The settlement is the center of government and residence (see: https://Jakarta.go.id ).

Tourism on the island began to develop in 2011. Tourists visiting Harapan Island were most compared to Kelapa Island, Panggang Island and Scout Island. Harapan Island is the island most visited by tourists. Tourists visiting Hope Island in 2017 are 95,179 people (Kepulauan Seribu Utara in Figure, 2018).

Most of the residents of Harapan Island are migrants from Bugis, Mandar, Banten, Java and other islands in the Thousand Islands (https://jakarta.go.id/artikel/konten/1678/kepulauan-seribu-taman-nasional) . The population of Harapan Island in 2016 was 2,368 people, consisting of 1200 male and 1168 female. The population structure of the Harapan Island Village is dominated by young people. Population density in Pulau Harapan Village is 9.68. The majority of the people of Harapan Island work as fishermen as many as 627 people, followed by 312 people as traders, 46 people as employees /army /police, 687 people as labours and 711 people in various other jobs. On Harapan Island there are 405 permanent homes, 156 semi-permanent houses and 65 permanent homes. Of the total permanent and semi-permanent homes, 163 of them are used as residences and homestays (Kepulauan Seribu Utara in Figure, 2018).

The rapid growth of tourist visits has caused many residents to become tourism service providers, such as catering, homestay, boat rental, and tour guides. According to the Chairman of the Thousand Islands Tourism Association 
the capacity of the population needs to be increased so that they are able to become tourism actors (Salangke, 2018), to increase population capacity Government agencies and other institutions have conducted various trainings. Office of the Thousand Islands Tourism and Culture often conducts training for homestay owners, tour guides and micro, small and medium enterprises. but there are some obstacles to the training (Pantriko and Arik, 2018), so training is still needed.

In order for homestay owners to run their business properly, the government has issued regulation on Minister of Tourism and Creative Economy number 9 on 2014 about homestay business standards. The homestay business is the provision of accommodation in the form of residential buildings inhabited by the owner and partially used for rent by providing an opportunity for tourists to interact in the daily life of their owners. The scope of these regulations include organizing, certificates and certification homestay, guidance and supervision, as well as administrative sanctions. Every homestay must have a homestay business certificate and carry out business certification. To get business certification, every homestay must meet the criteria of the homestay. Based on these regulations every homestay entrepreneur must meet business standards which includes products, services and management. To be able to apply the standard of the homestay business, training is needed.

At present there are still many tourism businesses that do not have business certificates. Although business certificates are important for consumers, the interest of entrepreneurs to obtain business certificates is still low. According to the chairman of the Indonesian Tourism Business Association in Indonesia called Gabungan Pengusaha Pariwisata Indonesia (GIPI), this is due to the lack of awareness of business people, there are no strict sanctions, the number of business certification institutions is still limited (Projo, 2017). Empirical research conducted by Wijayanti, Abdilah, Mawardi (2016), non-star hotel owners is not interested in business certification classified as low because of the high cost, lack of understanding of business certification, lack of socialization from the government and limited number of employees who have competency certificates.

Traning is a systematic approach to influence knowledge, attitudes and attitudes with the aim of influencing individuals, teams and organizational effectiveness (Goldstain and Ford in Aguinis and Kraiger, 2009). Training is a planned activity aimed at developing knowledge, skills, moral values and understanding all aspects of life needed (UK Training Commission in Masadeh 2012). Based on several training definitions, Somasundaram and Egan (2004) conclude that focus training is the development or acquisition of knowledge, development or acquisition of expertise, improvement in performance and improvement of organizational efficiency.

Training on standard homestay business is aimed at homestay owners. After attending the training, it is expected that there will be an increase in knowledge and changes in behavior of homestay owners and have an impact on business change. The behavior change expected from homestay owners is the awareness of the need to do business according to the standards of the homestay business.

Training proved to be able to provide benefits for individuals, organizations and nations. Training enhances individual abilities such as tacit skills, communication, innovation, self-efficiency, and empowerment. The form of benefits for organization is profitability, sales. For the nation, training increases human capital which has an impact on economic growth (Aguinis and Kraiger, 2009). Because of these benefits, the training was chosen as a method to increase the capacity of homestay owners.

Training must be evaluated for future improvement. Training Evaluation is a technique for measuring whether a program can fulfill its objectives. Evaluation Training is a technique for measuring whether a program can fulfill its objectives. Training evaluation is measured based on training objectives, methods, changes in participant behavior and rewards for organization. training related to cognitive learning, training performance and transfer performance (Alvarez, Salas, Garovano, 2004).

\section{METHODS}

The training was held on June 19-21, 2019 in the Village Hall. The training was attended by 36 homestay owners. The description of the training participants is as follows.

The standard training material for the homestay business refers to Minister of Tourism and Creative Economy Regulation, number 9 in 2014 concerning the standard of homestay business and its attachments. Training materials cover regulatory, product, service and management aspects. The standard rules for homestay business include organizing homestays, business certificates and certifications, coaching and supervision and administrative sanctions. Homestay products include residential buildings, bedrooms, supporting facilities and kitchens. Service aspects include simple service procedures starting from ordering, recording, handling complaints, payment, room cleaning and information. Management aspects include administration, security and safety and human resources. The training objective was for participants to know the rules and standards of the homestay. 
The method used is reading training materials, lectures and discussions and self-reflection. Reading, lecture and discussion methods are considered effective for increasing understanding of concepts and techniques, while selfreflection methods are suitable for identifying problems and finding solutions to problems (Bennett-Levy, McManus, and Westling, 2009). In the self-reflection method, participants compare what has been done with the standard business regulations and discuss problems that they meet homestay standards. The training begins with a pre-test, then participants are given material and listen to the instructor's presentation. During the presentation interspersed with questions and discussions, after the trainees participated in the post test. Pre and post-test material refers to lecture material, discussion and self-reflection.

Training performance was assessed from the results of the pre and post-test of the trainees. Positive difference between pre and post-test shows that, research performance is classified as good, and vice versa. The average value of the pre-test is 6.79 , while the post-test value is 7.51 .

\section{RESULTS AND DISCUSSION}

The results of the pre-test showed that participants were wrong to answer questions about the right of guests to use the kitchen, the obligation to record guest identity, the availability of information on homestay rental prices and the development of human resources. The results of the discussion revealed that there are two types of homestays on Harapan Island, a homestay which is separate from the residence of the owner and homestay in the real sense of sharing the residence of homestay owners and guests. In the two types of homestays, homestay owners only provide drinking water and glasses. Tableware is provided by catering owners or homeowners, if guests order meals. The homestay owner has provided simple drinking utensils, but does not give guests the opportunity to use the kitchen.

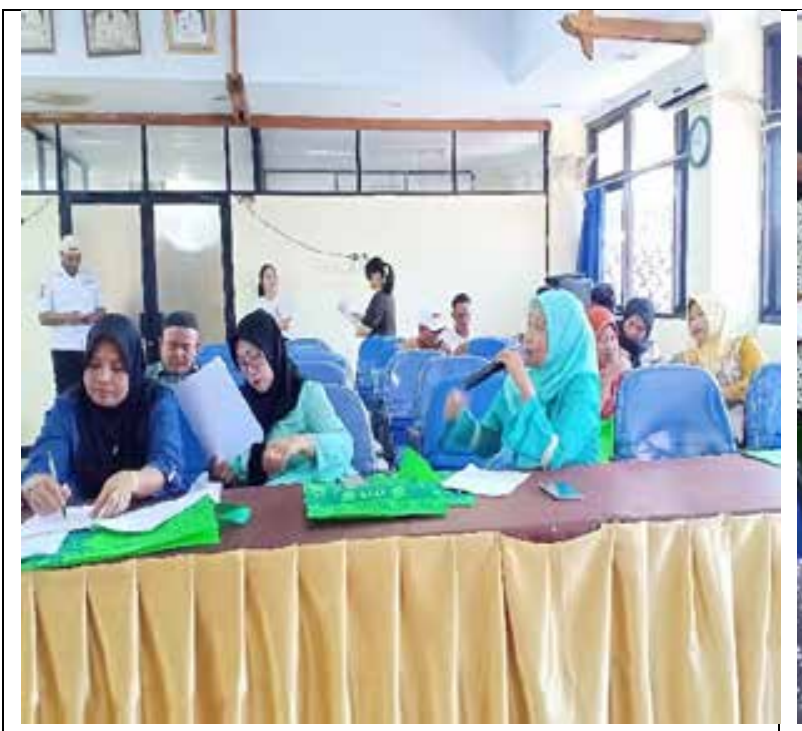

Picture 1. Discussing

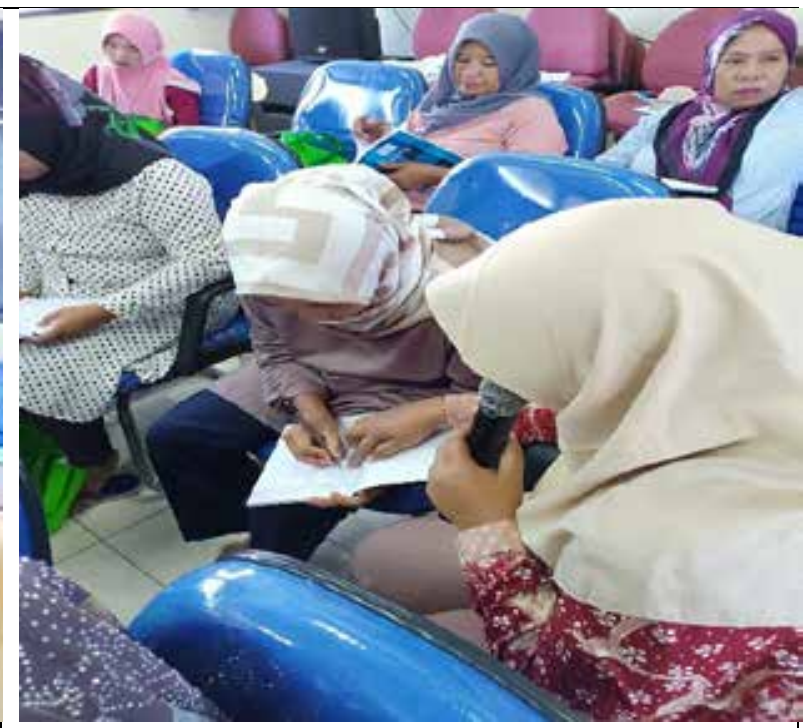

Picture 2. Coaching

Guest identity is often not recorded because the one who booked the homestay was a travel agent. Homestay owners often don't know who and how many people stay at their homestay. From the presentation and discussion, the participants realized the need to record the guest's identity. Guest identification is important for security and marketing. 


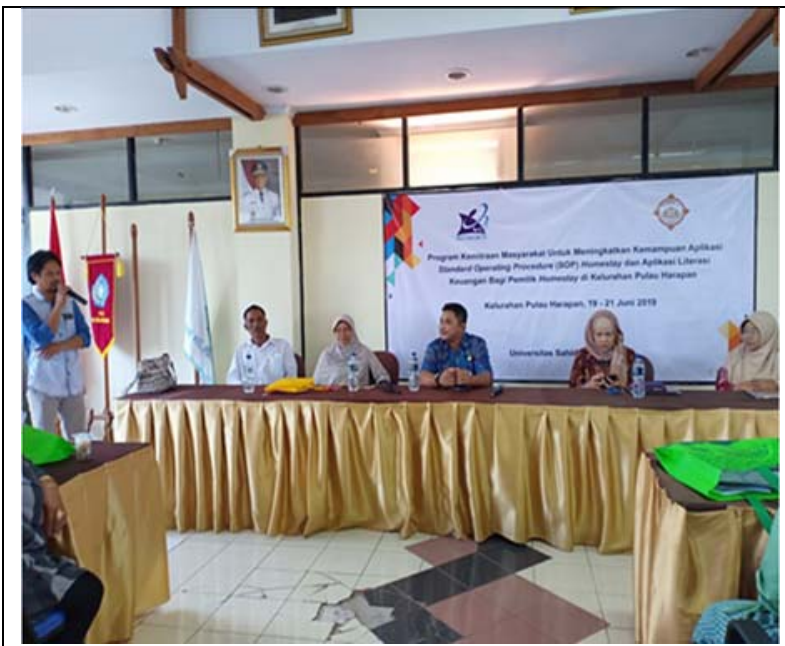

Picture 3. Closing ceremony

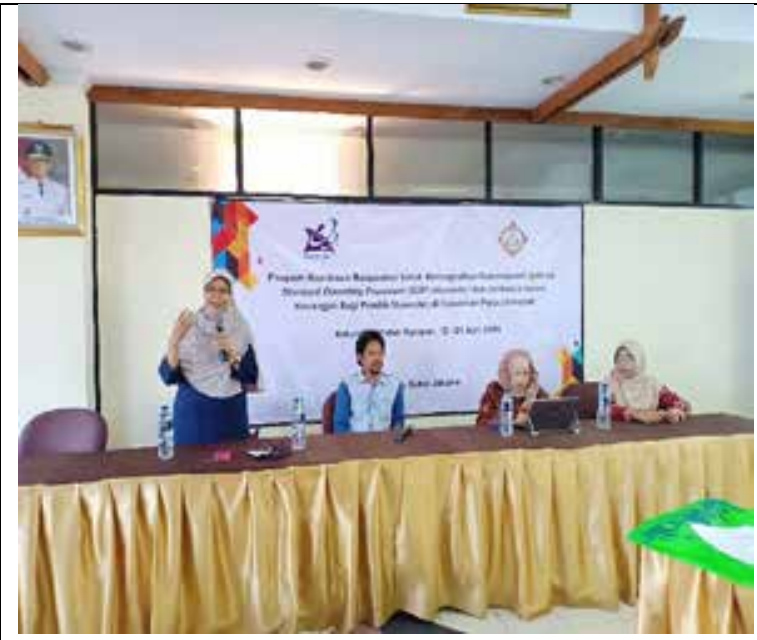

Picture 4. Presentation

So far, homestay owners do not provide price lists for guests. Most homestays are booked by travel agents who sell tour packages. From the presentation and discussion, participants realized the need to fulfill guest rights about prices.

Many homestay owners have not realized that homestays are not only products but also service and management. Most homestay owners only focus on the product. Homestay services received less attention because most of them thought that service was the responsibility of tour $\&$ travel. Management, also still lacks attention, especially those related to human resources. Training from government agencies and other agencies is still limited, so selfdevelopment is still limited.

\section{CONCLUSIONS AND RECOMMENDATIONS}

Standard homestay training for homestay owners on Harapan Island is able to increase the knowledge and acceptance of homestay owners on homestay standards set by the government. Training needs to be carried out extensively by the government or other institutions

The combination of reading, lecturing and discussion methods not only increases the knowledge of homestay owners but also increases the awareness of homestay owners about their rights and obligations.

\section{ACKNOWLEDGEMENT}

This research is funded by the Ministry of the Higher Education, Research and Technology of the Republic of Indonesia, through PKM program 2019 (Contract Number 11/AKM/P2M/2019). Thank you for homestay owner on Harapan Island who participated in the training.

\section{REFERENCES}

Aguinis, H. and Kraiger, K. (2009). Benefits of training and development for individuals and teams, organizations, and society. Annual Review of Psychology, 60, 451-474. http://dx.doi.org/10.1146/annurev.psych.60.110707.163505

Alvarez, K., Salas, E., and Garofano, C. M. (2004). An Integrated Model of Training Evaluation and Effectiveness. Human Resource Development Review, 3(4), 385-416. http://dx.doi.org/10.1177/1534484304270820

Bennett-Levy, J., McManus, F., Westling, B.E. and Fennell, M. (2009) Acquiring and Refining CBT Skills and Competencies: Which Training Methods Are Perceived to Be Most Effective? Behavioural and Cognitive Psychotherapy, 37, 571-583. https://doi.org/10.1017/S1352465809990270

Kepulauan Seribu, Taman Nasional, https://jakarta.go.id/artikel/konten/1678/kepulauan-seribu-taman-nasional Kepulauan Seribu Utara in Figure 2018, BPS-Statiistic of Kepulauan Seribu Regency

Masadeh, M. (2012). Training, education, development and learning: what is the difference? European scientific journal, 8(10). DOI:http://dx.doi.org/10.19044.

Projo, W.A. (2017) Sertifikasi Usaha Pariwisata Indonesia Belum Maksimal, Kompas.com, 18/03/2017,17:11 https://ravel.kompas.com/read/2017/03/18/171100127/sertifikasi.usaha.pariwisata.in donesia.belum.maksimal?page=all. . 
Salengke, H.H. (2018). Kepulauan Seribu Destinasi Baru, Mediaindonesia.com, 4/5/2018, 04:30 WIB. Disitasi dari https://mediaindonesia.com/read/detail/158764-kepulauan-seribu-destinasi-baru

Somasundaram, U. V., and Egan, T. M. (2004). Training and Development: An Examination of Definitions and Dependent Variables. Online Submission.

Wijayanti, A., Abdillah, Y., and Mawardi, M. K. (2016). Analisis Implementasi Sertifikasi USAha Pariwisata Bidang Perhotelan Di Kota Malang. Jurnal Administrasi Bisnis, 31(1), 192-198. 